\title{
MODEL PEMBELAJARAN DEBAT AKTIF BERBASIS ICT PADA MATERI KOLOID DAN KETERAMPILAN BERPIKIR KRITIS SISWA
}

\section{ICT-Based Active Debate Learning Model On The Material And Critical Thinking Skills Of Students}

\author{
Riza Zulfahnur*, Atiek Winarti, Syahmani
}

Program Studi Pendidikan Kimia FKIP Universitas Lambung Mangkurat,

Jl. Brigjend. H. Hasan Basry Banjarmasin 70123 Kalimantan Selatan Indonesia

*email: rizakimia15@gmail.com

\begin{abstract}
Abstrak. Tujuan penelitian ini untuk mengetahui keefektifan model pembelajaran debat aktif berbasis ICT dalam mengukur keterampilan berpikir kritis peserta didik. Secara khusus, penelitian ini memiliki tujuan yaitu: (1) Menganalisis perbedaan keterampilan berpikir kritis peserta didik yang belajar materi koloid dengan menggunakan model pembelajaran debat aktif berbasis ICT dan menggunakan model pembelajaran Ekspoiotori, (2) Mendiskripsikan respon peserta didik yang menggunakan model pembelajaran debat aktif berbasis ICT. Dalam penelitian ini dilaksanakan menggunakan metode kuasi eksperimen dengan desain penelitian pretest-posttest non equivalen group design sebanyak total tujuh kali pertemuan. Teknik pengambilan sampel dengan menggunakan purposive sampling, teknik pengambilan data menggunakan angket dan tes. Data instrumen penelitian yang diperoleh untuk dianalisis menggunakan uji-t. Hasil pada penelitian menunjukkan bahwa: (1) Terdapat perbedaan yang signifikan pada keterampilan berpikir kritis peserta didik antara pembelajaran model debat aktif berbasis ICT dengan model pembelajaran Ekspositori. (2) Penerapan model pembelajaran debat aktif berbasis ICT dapat memberikan respon positif pada peserta didik.
\end{abstract}

Kata kunci: debat aktif, ICT, berpikir kritis

\begin{abstract}
This study aims to test the effectiveness of ICT-based active debate learning models in measuring critical thinking skills of students. Specifically, the objectives of this study are: (1) To analyze the differences in critical thinking skills of students learning colloidal material using ICT-based active debate learning models and using the Expo learning model, (2) To describe students' responses using ICT-based active debate learning model. This research was conducted using a quasi-experimental method with a non-equivalent group pretest-posttest research design with a total of seven meetings. Purposive sampling is used as the sampling technique, and questionnaires and tests are used as the data collection techniques. The research instrument data obtained were analyzed using t-test. The results showed that (1) There is a significant difference in students' critical thinking skills between learning of ICT-based active debate models and Expository learning models. (2) The application of ICT-based active debate learning model can provide positive responses on students.
\end{abstract}

Keywords: active debate, ICT, critical thinking. 


\section{PENDAHULUAN}

Kebutuhan yang dibutuhkan peserta didik dimasa akan datang berupa kemampuan berpikir kritis, kreatif dan berkomunikasi tercantum dalam permendikbud No. 81 tahun 2013 tentang implementasi kurikulum (Kemendikbud, 2013). Peserta didik sebaiknya menambah suatu keterampilan, yakni berpikir kritis pada abad 21 untuk menyongsong revolusi industri 4.0 dan kurikulum 2013 (K13). Pembelajaran kimia yang terbaru dilaksanakan menggunakan kurikulum pembelajaran 2013 yang menuntut peseta didik agar memiliki keterampilan berpikir kritis.

Berdasarkan pengalaman selama melakukan praktek mengajar di sekolah ditemukan beberapa hal, di antaranya: pada saat guru memberikan sebagian besar peserta didik hanya menerima informasi tanpa mempertanyakan sumber informasi tersebut, kurang menanggapi pernyataan atau pendapat yang diungkapkan oleh temannya, jarang menggali lebih sebuah informasi baik dari sebuah pernyataan ataupun pertanyaan yang pernah didiskusikan. Guna meningkatkan sebuah keterampilan yakni berpikir kritis peserta didik diperlukan sebuah pola pembelajaran yang mengembangkan pola pikir dan mengikutsertakan peserta didik dalam proses pembelajaran aktif. Pola pembelajaran aktif dapat kita kembangkan dengan adanya melibatkan langsung atau adanya interaksi peserta didik pada proses pembelajaran sehingga terciptanya student centered yakni, pembelajaran yang agar membentuk peserta didik menjadi pusat pembelajaran.

Pembelajaran itu akan mendorong untuk membangun pengetahuannya peserta didik itu sendiri yang akan konsep dalam sebuah materi pembelajaran. Peserta didik bukan hanya menerima apa yang sampaikan, tetapi juga aktif mencari dan memilah informasi yang diperlukan sesuai dengan materi pembelajaran. Peran guru cenderung hanya sebagai seseorang yang memfasilitasi proses pembelajaran sehingga peserta didik mampu membentuk pengetahuan tersebut. Salah satu cara kiranya yang dapat meningkatkan keterampilan berpikir kritis peserta didik yaitu dengan memilih model pembelajaran yang sesuai, yakni pembelajaran debat aktif. Model ini akan memungkinkan peserta didik untuk berperan lebih aktif karena didalam model pembelajaran ini terdapat kegiatan diskusi, tukar pendapat serta mengkritisi pendapat lainnya. Selaras dengan hasil dari penelitian yang pernah dilaksanakan oleh (Nurchabibah, 2011) yang menunjukkan bahwa dalam penggunaan metode Debat Aktif dapat meningkatkan kemampuan berbicara khususnya keterampilan diskusi.

Penelitian (Widodo, Qosyim, \& Pramesswari, 2016) Menunjukan keterampilan berpikir kritis meningkat dengan diterapkannya strategi debat aktif pada suatu materi, yakni pemanasan global peningkatan terjadi disetiap aspeknya namun dalam pelaksanaan memerlukan waktu yang cukup lama karena harus memiliki datadata yang relavan untuk dapat memahami mosi ataupun permasalahan-permasalahan yang telah diberikan sehingga dapat mengeluarkan pendapat dan berargumen yang kuat. Berdasarkan hal tersebut, perlu adanya pendukung untuk kelancaran debat aktif serta memenuhi keterjaminan mutu materi pada debat aktif maka diperlukan Information and Communication Technology (ICT). ICT dapat mempermudah peserta didik untuk memudahkan proses penyampaian argumen dalam pembelajaran.

Berdasarkan uraian itu peneliti melakukan penelitian tentang penerapan model pembelajaran debat aktif berbasis ICT pada koloid dalam peningkatan keterampilan berpikir kritis peserta didik di kelas XI IPA SMA Negeri 1 Banjarmasin.

\section{METODE PENELITIAN}


Metode dalam penelitian ini adalah eksperimen semu (quasy experiment) melalui desain pretest-posttest non equivalen group design. Sampel pada penelitian ini adalah 64 orang, yakni pada kelas eksperimen sebanyak 32 orang dan kelas kontrol sebanyak 32 orang orang. Pemlajaran sebanyak empat pertemuan kelas eksperimen. Penelitian menggunakan teknik pengumpulan data menggunakan teknik tes keterampilan berpikir kritis yang dilakukan pada pertemuan awal dan akhir dan nontes berupa obsevasi keterampilan berpikir kritis beserta angket respon melalui analisis deskriptif dan analisis inferensial.

Hasil dari keterampilan berpikir kritis terhadap peserta didik kemudian dianalisis dengan melakukan uji beda, yakni uji-t. Instrumen tes berupa 9 soal uraian disertakan alasan dan respon peserta didik dianalisis menggunakan analisis deskriptif. Adapun pengkategorian keterampilan berpikir kritis menurut (Widoyoko, 2016) dengan kategori tidak kritis, kurang kritis, cukup kritis, kritis dan sangat kritis.

\section{HASIL PENELITIAN DAN PEMBAHASAN \\ Hasil Penelitian \\ Analisis Keterampilan Berpikir Kritis}

Perbandingan XI IPA 3 (eksperimen) dan XI IPA 2 (kontrol) setelah diberi perlakuan dianalisis. Tes dilakukan awal pertemuan dan akhir pertemuan untuk mendapat data keterampilan berpikir kritis peserta untuk membandingkan antara dua kelas tersebut. Setelah digunakan uji-t untuk menghitung disimpulkan kedua kelas berbeda secara signifikan.

Perbedaan terjadi karena pembelajaran dengan menggunakan model pembelajaran debat aktif berbasis ICT khususnya aplikasi padlet mendorong peserta didik untuk aktif dalam berpendapat aktif saat berdebat serta membuat peserta didik lebih mengeksplorasi secara independen, sehingga peserta didik terbiasa. Sedangkan kelas kontrol digunakan model pemeblajaran Ekspositori peserta didik tidak banyak diberikan untuk aktif. Hal ini terdapat pada Tabel 1 uji-t dan Tabel 2 nilai $N$-Gain

Tabel 1. Rata-rata nilai N-Gain

\begin{tabular}{lcccc}
\hline \multirow{2}{*}{ Indikator } & \multicolumn{2}{c}{ Kontrol } & \multicolumn{2}{c}{ Eksperimen } \\
\cline { 2 - 5 } & $\langle\mathbf{g}\rangle$ & Tingkat Pencapaian & $\langle\mathbf{g}\rangle$ & $\begin{array}{c}\text { Tingkat } \\
\text { Pencapaian }\end{array}$ \\
\hline Klasifikasi Makna & 0,36 & Sedang & 0,38 & Sedang \\
Pengkajian Data & 0,44 & Sedang & 0,51 & Sedang \\
Menarik & 0,53 & Sedang & 0,72 & Tinggi \\
Kesimpulan & & & & \\
Menilai Argumen & 0,49 & Sedang & 0,68 & Sedang \\
Mempresentasikan & 0,62 & Sedang & 0,76 & Tinggi \\
Argumen & & & & Sedang \\
Rata-rata & 0,49 & Sedang & 0,61 & \\
\hline
\end{tabular}

Berdasarkan mean N-gain untuk kelima indikator keterampilan beripikir kritis diTabel 18 terlihat nilai $\mathrm{N}$-gain di kelas eskperimen lebih tinggi dari pada kelas kontrol yaitu sebesar 0,61 dan 0,49. Namun masih berada dalam tingkat pencapaian yang sama yaitu kategori sedang.

Pada kelas eksperimen, indikator keterampilan berpikir kritis mengalami tingkat pencapaian tinggi pada indikator menarik kesimpulan dan mempresentasikan argumen. Sedangkan indikator lainnya seperti, klasifikasi makna, pengkajian data, menilai argumen dan mempresentasikan argumen masih berada pada tingkat pencapaian sedang. Sedangkan di kelas kontrol seluruh indikator berada ditingkatan 
sedang. Peningkatan dialami oleh seluruh nilai $\mathrm{N}$-gain di kelas eksperimen meskipun sebagian besar berada pada tingkatan pencapaian yang sama dengan kelas control.

\section{Hasil Analisis Inferensial Keterampilan Berpikir Kritis}

Dilakukan uji pendahuluan (uji normalitas serta uji homogenitas) sesaat sebelum melakukan analisis inferensial dengan menggunakan uji beda (uji-t) untuk data hasil dari pre-test keterampilan berpikir kritis peserta didik di kelas kontrol dan kelas eksperimen.

Setelah dilakukan uji normalitas baik data pre-test maupun post-test yang diperoleh dari kedua kelas memiliki distribusi normal. Hasil dari uji homogenitas baik untuk pre-test ataupun post-tes memeperlihatkan varian data pada kedua kelas tersebut sebelum diberi perlakuan cenderung tidak berbeda yang berarti data homogen.

Tabel 2. Hasil uji-t data pre-test dan post-test keterampilan berpikir kritis

\begin{tabular}{ccccccc}
\hline Hasil & Kelas & $\boldsymbol{N}$ & Sig. (2-tailed) & $\mathbf{t}_{\text {hitung }}$ & $\mathbf{t}_{\text {tabel }}$ & Kesimpulan \\
\hline Pre-test & $\begin{array}{c}\text { Kontrol } \\
\text { Eksperimen } \\
\text { Kontrol }\end{array}$ & 32 & 0,061 & $-1,911$ & 1,99 & $\begin{array}{c}\text { Tidak } \\
\text { Signifikan }\end{array}$ \\
Post-test & $\begin{array}{c}\text { Eksperimen } \\
\text { Eknon }\end{array}$ & 32 & 0,000 & $-8,312$ & 1,99 & Signifikan \\
\hline
\end{tabular}

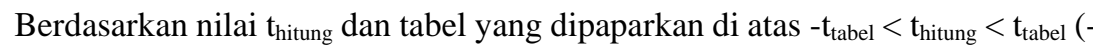
$1,99<-1,911<1,99)$ atau dapat diamati dari nilai sig. sebesar $0,061>\alpha$ sebelum memberikan perlakuan maka dapat disimpulkan $\mathrm{H}_{0}$ bahwa diterima sehingga dapat dinyatakan tidak ditemukan perbedaan yang signifikan antara rata-rata nilai keterampilan berpikir kritis yang didapat di kelas kontrol ataupun kelas eksperimen. Berdasarkan harga pada hasil $t_{\text {hitung }}$ serta $t_{\text {tabel }}$ di mana $t_{\text {hitung }}<-t_{\text {tabel }}(-8,312<-1,99)$ atau dapat dilihat dari nilai sig. sebesar $0,000<\alpha=0,05$ setelah memberikan perlakuan maka dapat disimpulkan $\mathrm{H}_{1}$ dapat diterima. Jadi dapat disebutkan bahwa ditemukan perbedaan yang signifikan antara rata-rata nilai keterampilan berpikir kritis peserta didik di kedua kelas.

\section{Pembahasan}

Model pembelajaran debat aktif digunakan di kelas eksperimen pada penelitian ini berbantuan ICT. ICT yang digunakan, yaitu aplikasi padlet. Dalam proses pembelajaran peserta didik diberikan kesempatan melakukan kegiatan debat terdiri dari kegiatan mengungkapkan pendapat, mengkaji ulang, megkritisi dan menemukan solusi pada padlet seperti pernyataan (Fuchs, 2014) menyatakan bahwa, dengan menggunakan padlet peserta didik dapat berpartisipasi dalam diskusi dan aktivitas, mengajukan pertanyaan, dan memberikan pendapat sehingga membuat kelas tidak jenuh dan bisa dilaksanakan. Aplikasi padlet mendorong peserta didik lebih aktif debat karena beberapa vitur seperti dapat mengirim dokumen, photo, vedio dan sebagainya yang memudahkan peserta didik mengeluarkan pendapatnya. Keaktifan peserta didik diharapkan mampu meningkatkan keterampilan berpikir kritisnya. Hal ini sejalan oleh penelitian (Chalimawati, 2019) menyebutkan bahwa "Pembelajaran kimia melalui model pembelajaran kooperatif debat kimia berbasis ICT dapat merangsang keterampilan berpikir kepada peserta didik dan dapat juga memberikan peningkatan pemahaman peserta didik."

Sebelum melaksanakan pembelajaran dilakukan pre-test guna melihat keterampilan peserta didik sebelum diberikan perlakuan. Kemudian setelah empat kali pertemuan dilaksanakan post-test. Hasil dari penelitian memperlihatkan bahwa 
rata-rata keterampilan berpikir kritis yang didapat peserta didik di kelas eksperimen mengalami peningkatan dari kategori kurang kritis menjadi kekategori sangat kritis dan kelas kontrol dari kategori tidak kritis menjadi kategori kritis. Perbedaan yang signifikan dari nilai rata-rata post-test keterampilan berpikir kritis kelas eksperimen maupun kelas kontrol ditunjukkan melalui hasil analisis inferensial. Berikut dipaparkan hasil keterampilan berpikir kritis perindikator:

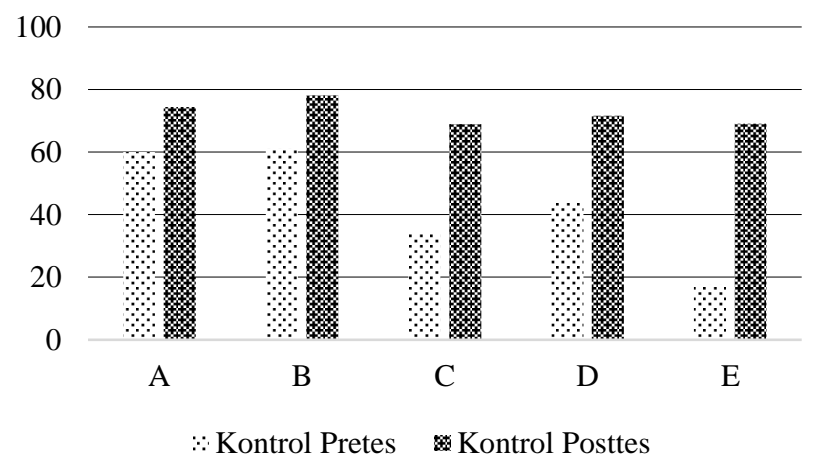

Gambar 1. Tingkat pencapaian keterampilan berpikir kritis kelas kontrol di setiap indikator

Keterangan;

A : Klasifikasi Makna

B : Pengkajian Data

C : Menarik Kesimpulan

D : Menilai Argumen

E : Mempresentasikan Argumen

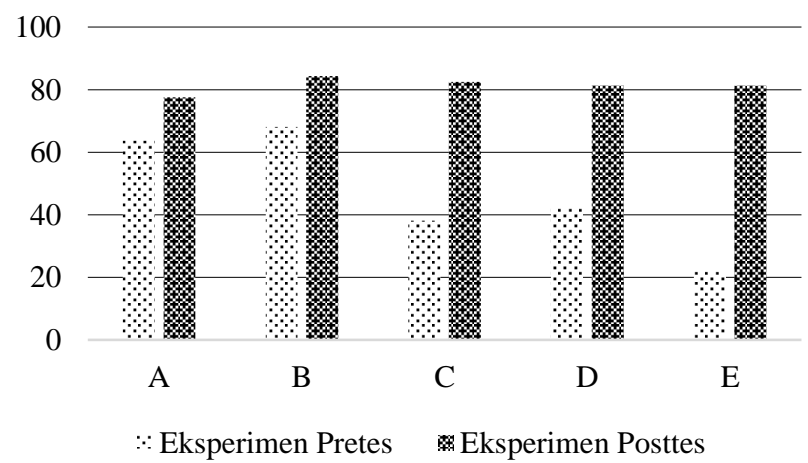

Gambar 2. Tingkat pencapaian keterampilan berpikir kritis kelas eksperimen di setiap indikator

Keterangan;

A : Klasifikasi Makna

B : Pengkajian Data

C : Menarik Kesimpulan

D : Menilai Argumen

E : Mempresentasikan Argumen 
Berdasarkan Gambar 1 dan Gambar 2, indikator dengan tingkat pencapaian tertinggi pada post-test kelas kontrol ataupun kelas eksperimen yaitu indikator pengkajian data dengan persentase sebesar $78,13 \%$ dan $84,38 \%$. Terlihat pula bahwa tingkat ketercapaian pada indikator keterampilan berpikir kritis terhadap peserta didik pada kelas eksperimen dan kelas kontrol terjadi berbeda-beda.

Beberapa penyebabnya yakni, pertama pembelajaran model debat aktif berbasis ICT kelas eksperimen dapat merangsang keaktifan peserta didik dalam berargumen melalui aplikasi padlet dan mendorong peserta didik mencari informasi dari berbagai sumber yang ada. Hal ini didukung juga penelitian oleh (Wahdan, Sulistina, \& Sukariningsih, 2017) menyimpulkan bahwa kemampuan berargumen dapat meningkat karena terlibat aktifnya peserta didik sehingga terjadi interaksi argumen dan menganalisis argumen. Kedua peserta didik kelas eksperimen sudah melakukan kajian terhadap mosi ataupun pada sumber yang didapat oleh peserta didik sendiri. Sementara peserta didik kelas kontrol kurang melakukan kajian karena tidak ada pernyataan yang kontroversi seperti pernyataan (Winarti \& Fauji, 2015) yakni, "model pembelajaran dengan pendekatan kontruktivisme dapat memberi peningkatan keterampilan berpikir kritis terhadap siswa dari kategori cukup baik menjadi baik."

Indikator pertama klasifikasi makna terlihat perbedaan pada kelas kontrol dan eksperimen yaitu kelas eksperimen sedikit lebih bagus daripada kelas kontrol. Hal itu terjadi karena model debat menggunakan aplikasi padlet dapat mendorong peserta didik untuk mencari bahan dan membangkitkan peserta didik aktif dalam berargumen. Hal itu seperti penelitian oleh (Pratama, Nurcahyo, Hertanto, Marina, Rosyidah, \& Kristianto, 2016) yaitu aplikasi padlet dapat memudahkan peserta didik untuk menyampaikan argumen dan peserta didik lebih bebas berargumen.

Indikator kedua pengakajian data, dalam indikator kedua terjadi perbedaan yang sangat signifikan di kelas kontrol dan eksperimen. Perbedaan ini terjadi karena kelas eksperimen terdapat problem kontroversi sehingga membuat peserta didik mencari data yang sesuai dengan problem dengan adanya aplikasi padlet yang terdapat berbagai vitur yang menarik dapat membantu peserta didik untuk melampirkan datanya beserta argumennya. Hal itu tidak berbeda dengan hasil temuan oleh (Suryadi, 2007) yang menyatakan pembelajaran e-learning dapat membuat peserta didik antusias dalam pembelajaran karena dapat menggali informasi yang menarik. Hal serupa juga terdapat pada penelitian (Kirna, Sudria, \& Tegeh, 2015) yang menemukan bahwa ICT dapat membuat peserta didik tertarik atau tidak bosan karena bisa mendapatkan infromasi yang lebih luas.

Indikator ketiga menarik kesimpulan terdapat perbedaan antara kelas eksprimen menggunakan model debat aktif berbasis ICT dengan kelas kontrol menggunakan model ekspositori dikarenakan kelas eksperimen terbiasa menarik kesimpulan argumen orang lain dalam debat sedangkan kelas kontrol tidak terbiasa sehingga kelas eksperimen lebih baik. Hal ini sejalan dengan penilitian oleh (Fauziyah, 2019) pembelajaran yang menggunakan debat dapat meningkatkan kemampuan berargumen peserta didik dalam preses debat.

Indikator keempat menilai argumen juga menunjukan perbedaan yang cukup signifikan. Khasus ini terjadi karena pegunaan model debat aktif berbasis ICT di kelas eksperimen menjadikan peserta didik lebih aktif dalam berargumen serta terjadi komunikasi satu dengan yang lainnya sedangkan kelas kontrol kurang aktif. Hal ini juga sesuai dengan penilitian oleh (Maulina, Mashudi, \& Sulistyarini, 2016) menyimpulkan bahwa debat dapat meningkatkan komunikasi peserta didik.

Indikator kelima mempresentasikan argumen memiliki perbedaan signifikan karena kelas eksperimen penggunakan model pembelajaran debat aktif berbasis ICT di kelas eksperimen yang membuat peserta didik untuk aktif berargumen pada 
aplikasi padlet dalam debat tersebut. Adanya padlet membuat peserta didik tidak takut mengeluarkan argumen dan memberikan waktu berlebih untuk berpikir karena dalam padlet kita dapat membaca argumen kapanpun secara berulang. Hal ini didukung oleh (Firdauzi, Widiantie, \& Handayani, 2019) Pendalaman materi dapat dilakukan dalam proses debat yang berkaitan dengan mosi kemudian peserta didik memunculkan kesimpulan sehingga dapat memahami materi yang Ia baca maupun argumen lawan.

Selanjutnya, ketiga peserta didik terbantu dengan ada aplikasi padlet yang dapat melampirkan referensi pada saat debat atau argumen serta dapat memberikan memberikan kesempatan waktu berpikir lebih lama. Akibatnya peserta didik terbiasa berkontribusi dalam melakukan kajian dan mengumpulkan data-data yang berkaitan dengan pembelajaran koloid untuk berdebat. Keempat peserta didik aktif berargumen pada aplikasi padlet dalam debat tersebut. Adanya padlet membuat peserta didik tidak takut mengeluarkan argumen dan memberikan waktu berlebih untuk berpikir karena dalam padlet kita dapat membaca argumen kapanpun secara berulang. Hal ini sejalan dengan penelitian (Syahmani, Iriani, \& Aisyah, 2018) menyebutkan bahwa pembelajaran menggunakan e-learning mampu membuat peserta didik antusias serta aktif dalam belajar karena e-learning memberikan kebebasan belajar pada peserta didik

Berdasarkan penelitian (Nurviyani, 2018) bahwa aplikasi padlet dapat mempermudahkan mahasiswa untuk membaca dengan waktu kapan saja dan dimana saja serta dapat melampirkan erbagai vitur-vitur seperti dokumen, video dan sebagainya. Adapun pada kelas kontrol dengan model ekspositori, peserta didik hanya mendapat gambaran melalui penjelasan guru. Kemudian hasil respon peserta didik setelah dilaksanakan pembelajaran di kelas eksperimen ditampilkan pada gambar berikut.

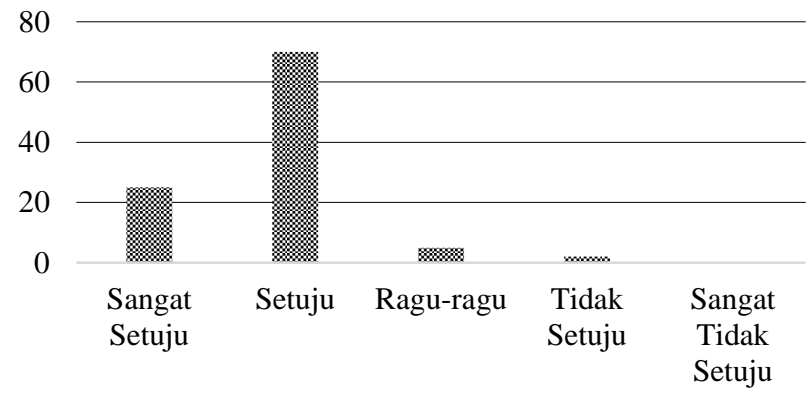

Respon Peserta Didik

\section{Gambar 3. Hasil respon peserta didik}

Berdasarkan data di atas dapat dinyatakan rata-rata respon peserta didik termuat dalam kategori setuju. Pernyataan itu menunjukkan bahwa peserta didik memberikan respon dengan baik pada penggunaan model pembelajaran debat aktif berbasis ICT pada materi koloid.

\section{SIMPULAN}

Diperoleh perbedaan signifikan keterampilan berpikir kritis peserta didik dengan pembelajaran debat aktif berbasis ICT dan model pembelajaran ekspositori di kelas XI IPA SMA Negeri 1 Banjarmasin kemudian peserta didik menanggapi dengan respon positif kepada penerapan model pembelajaran debat aktif berbasis ICT melalui aplikasi padlet 
Berikut saran yang dapat penulis utarakan berlandaskan hasil penelitian yang diperoleh yaitu (1) Kepada peserta didik, melalui penerapan model debat aktif berbasis ICT diharapkan agar lebih mendalami mosi yang telah diberikan; (2) Kepada guru, disarankan jika menerapkan model debat aktif berbasis ICT lebih memperhatikan mekanisme debat pada peserta didik agar terarah pada mosi, mengatur waktu agar debat berlangsung efektif, efisien dan menyusun mosi yang menarik serta actual; (3) Kepada kepala sekolah, sebaiknya model ini di masukan sebagai alternatif untuk memberi peningkatkan kualitas mutu pengajaran atau bahkan pada mata pelajaran lainnya; (4) Kepada peneliti lain, memandang banyaknya keterbatasan dipenelitian ini semoga peneliti lain memperhatikan dalam pembuatan mosi agar sesuai dengan perkembangan zaman.

\section{DAFTAR RUJUKAN}

Chalimawati, Y. (2019). Peningkatan hasil belajar kimia melalui model kooperatif debat kimia berbasis ICT siswa SMAN. Jurnal Untan, 17-27.

Fauziyah. (2019). Pembelajaran model inquiri training berbantu metode debat untuk meningkatkan kemampuan berargumentasi dan hasil belajar siswa pada mata pelajaran pendidikan agama islam di kelas XI SMA Negeri 7 Cirebon. Jurnal Pendidikan, 4(4), 101-114.

Firdauzi, Widiantie, \& Handayani. (2019). Penerapan model pembelajaran PBL dipadu metode debat terhadap kemampuan berargumen. Jurnal Pendidikan dan Biologi, 11(3), 49-54.

Fuchs, B. (2014). The Writing in on the wall: Using Padlet for Ehole-Class engagement. Loex Quarterly, 3(4), 7-9.

Kemendikbud. (2013). Kemendikbud. Retrieved September 19, 2018, from Karakteristik berpikir peserta didik: www.Kemendikbud.go.id/Main

Kirna, M. I., Sudria, N. B., \& Tegeh, M. I. (2015). Apa Respoden dan harapan siswa SMA tentang Blanded Learning. Jurnal Pendidikan dan Pengajaran, 3(5), 1536.

Maulina, Mashudi, \& Sulistyarini. (2016). Efektivitas pembelajaran metode debat terhadap kemampuan berpikir kritis dan kemampuan berkomunikasi pada mata pelajaran ekonomi. Jurnal Pendidikan Untan, 5(6), 1-17.

Nurchabibah. (2011). Keefektifan metode debat aktif dalam pembelajaran diskusi pada siswa kelas X SMA Negeri 1 Kutowinangun. Program Studi Bahasa dan Sastra Indonesia Fakultas Bahasa dan Seni Universitas Yogyakarta, 5(2), 7179.

Nurviyani, V. (2018). Fostering college students critical reading skill through padlet aplication. Jurnal Pendididkan Bahasa dan Satra, 17(4), 66-74.

Pratama, H., Nurcahyo, K., Hertanto, M. A., Marina, R., Rosyidah, S., \& Kristianto, V. A. (22016). Panduan Debat Kompetitif. Yogyakarta: Andi.

Suryadi, A. (2007). Pemanfaatan ICT dalam pembelajaran. Jurnal Pendidikan Terbuka Jarak Jauh, 8(3), 83-98.

Syahmani, Iriani, B., \& Aisyah, N. (2018). Pengaruh E-learning berbasis Schoology pada hasil belajar dan keterampilan pemecahan masalah di indonesia kimia. Advances in Social Science, Education and Humanities Research, 274(5), 301307.

Wahdan, W. Z., Sulistina, O., \& Sukariningsih, D. (2017). Analisis kemampuan berargumen ilmiah materi ikatan kimia peserta didik SMA, MAN dan Perguruan Tinggi Tingkat I. J-PEK, Jurnal Pembelajaran Kimia, 2(2), 30-40.

Widodo, W., Qosyim, A., \& Pramesswari, A. S. (2016). Penerapan strategi debat aktif untuk melatihkan keterampilan berpikir kritis. Jurnal Pendidikan Sains, 7(3), 


\section{MODEL PEMBELAJARAN DEBAT AKTIF BERBASIS ICT}

$17-24$.

Widoyoko, E. P. (2016). Teknik Penyususan Intrumen Penelitian. Yogyakarta: Pustaka Belajar.

Winarti, A., \& Fauji, A. (2015). Meningkatkan keterampilan berpikir kritis dan hasil belajar siswa melalui model pembelajaran Auditory, Intellectually, Repetition (AIR) pada materi hidrolisis garam di kelas XI IPA 2 SMA PGRI 6 Banjarmasin. Quantum Jurnal Inovasi Pendidikan, 6(2), 1-10. 